\title{
THERMAL STABILITY OF ALLOYS 718 AND ALLVAC 718-ER ${ }^{k}$
}

\author{
W. D. Cao and R. L. Kennedy \\ Allvac, An Allegheny Technologies Company \\ 2020 Asheraft Avenue \\ Monroe, North Carolina 28110
}

\begin{abstract}
Thermal stability of Allvac ${ }^{\mathrm{r}}$ alloy $718-\mathrm{ER}^{3}$ and alloy 718 was evaluated by the change in microstructure and mechanical properties after long time thermal exposure. The major microstructural changes due to thermal exposure included $\gamma^{\prime \prime}$ and $\gamma^{\prime}$ particle growth. formation of a $\gamma^{\prime \prime}$-depletion zone, and occurrence of large. blocky particles resulting from $\gamma^{\prime \prime}$ to $\delta$ phase transformation. All three changes were quite similar in both alloys, indicating that $\mathrm{P}$ and $\mathrm{B}$ did not have a noticeable effect on microstructural degradation in alloy 718 . Tensile strength at room and elevated temperatures dropped 10-17\% after thermal exposure in both alloys. Stress rupture life was reduced by nearly $90 \%$, but creep resistance dropped by more than two orders of magnitude. The degradation of creep rupture properties in terms of percentage reduction was significantly greater in alloy 718 -ER, and most of the improvement from $\mathrm{P}$ and $\mathrm{B}$ modification was lost after thermal exposure. The strengthening effect of $\mathrm{P}$ and $\mathrm{B}$ modification was also a function of test temperature.
\end{abstract}

It was concluded that $\mathrm{P}$ and $\mathrm{B}$ did not increase the thermal stability of alloy 718 at $704^{\circ} \mathrm{C} \mathrm{x}$ 1000 hrs. exposure and that the loss of rupture and creep properties was caused mainly by $\gamma^{*}$ dissolution and the formation of a $\gamma$ "-depleted zone at grain boundaries. The effect of $\mathrm{P}$ and $\mathrm{B}$ on rupture and creep properties of alloy 718 appears to be closely associated with $\gamma^{*}$ precipitates.

718-ER is a registered trademark of ATI Properties, Inc.

Superalloys 718.625 .706 and Various Derivatives

Edited by E.A. Loria

IMS (The Minerals. Metals \& Materials Society) 2001 


\section{Introduction}

Alloy 718 -ER is a modified 718 with higher $\mathrm{P}$ and $\mathrm{B}$ contents, and previous studies have shown that the stress rupture and creep properties were improved by more than $100 \%$ in comparison with that of standard alloy $718[1-5]$. No evaluation has been performed of the thermal stability of alloy 718 -ER although this information is critical for assessing temperature capability.

It is well known that alloy 718 is unstable at elevated temperatures, especially after long-term exposure at temperatures of $650^{\circ} \mathrm{C}$ or above [6-9]. A number of microstructural changes occur during long-term exposure at high temperature, including coarsening of $\gamma^{\prime \prime}$ and $\gamma^{\prime}$ particles and the partial dissolution of $\gamma^{\prime \prime}$ and $\gamma^{\prime}$ with concurrent formation of $\delta$ phase particles. The dissolution of $\gamma^{\prime \prime}$ occurs preferentially at grain boundaries and around $\delta$ phase particles, leading to the formation of $\gamma$ "-depleted zones at those locations. Much attention has been paid to characterization of the morphological changes and coarsening kinetics of $\gamma^{\prime \prime}$ and $\gamma^{\prime}$ particles. but little work has been done to correlate mechanical property degradation with specific microstructural changes.

It has been shown [1,9] that both $\mathrm{P}$ and $\mathrm{B}$ heavily segregate to grain boundaries, which could influence the microstructural changes occurring during long-term high temperature exposure, but it is not known whether they affect the thermal stability of alloy 718 . The mechanisms responsible for the improvement in creep and stress rupture life by $\mathrm{P}$ and $\mathrm{B}$ additions in alloy 718 are not well understood. Study of their effect on thermal stability may provide further evidence for clarifying these mechanisms.

\section{Experimental Procedures}

The chemistries of materials used in this study are listed in Table I. Two 9080-kg vacuum induction melted, $508 \mathrm{~mm}$ Rd triple melted heats were made consecutively with the first heat being standard 718 and the second alloy 718-ER. All ingots were homogenized at identical conditions and forged in the same manner to $203 \mathrm{~mm}$ billets. Test materials were taken from the same ingot location of these two heats. Longitudinal test sample blanks were cut from the midradius location and subjected to a solution treatment of $954^{\circ} \mathrm{C} \times 1 \mathrm{hr}$.. air cooled and then aged for $8 \mathrm{hrs}$. at $718^{\circ} \mathrm{C}$. furnace cooled at $55^{\circ} \mathrm{C} / \mathrm{hr}$. to $621^{\circ} \mathrm{C}$, held at $621^{\circ} \mathrm{C}$ for $8 \mathrm{hrs}$. air cooled. Half of the blanks were further aged at $704^{\circ} \mathrm{C}$ for $1000 \mathrm{hrs}$. and used for evaluating thermal stability.

Table I. Chemical Compositions of Alloys 718 and 718-ER ${ }^{\mathrm{R}}$

\begin{tabular}{|c|c|c|c|c|c|c|c|c|c|c|c|}
\hline & \multicolumn{10}{|c|}{ Chemistry (wt.\%) } \\
\cline { 2 - 13 } Alloy & $\mathrm{C}$ & Mo & $\mathrm{Cr}$ & $\mathrm{Ni}$ & $\mathrm{Fe}$ & $\mathrm{Nb}$ & $\mathrm{Ti}$ & $\mathrm{Al}$ & $\mathrm{P}^{*}$ & $\mathrm{~B}^{*}$ & $\mathrm{~S}^{*}$ \\
\hline $\begin{array}{c}718 \\
\text { (JG60) }\end{array}$ & .022 & 2.90 & 18.0 & $\mathrm{Bal}$ & 17.4 & 5.36 & 0.96 & 0.57 & 60 & 40 & 4 \\
\hline $\begin{array}{c}718 \mathrm{ER} \\
\text { (JG61) }\end{array}$ & .023 & 2.92 & 17.9 & $\mathrm{Bal}$ & 17.5 & 5.39 & 0.99 & 0.57 & 220 & 77 & 4 \\
\hline
\end{tabular}

* in ppm.

Room temperature and $650^{\circ} \mathrm{C}$ tensile tests, stress rupture tests at $650^{\circ} \mathrm{C} / 690 \mathrm{MPa}$ and $704^{\circ} \mathrm{C}$ $620 \mathrm{MPa}$. and creep tests at $621^{\circ} \mathrm{C} / 620 \mathrm{MPa}$ were run on both alloys in the as-heat treated and as-heat treated $+704^{\circ} \mathrm{C} \times 1000$ hrs. thermally exposed conditions. 
The microstructures of all test alloys were examined by optical microscope and scanning electron microscope (SEM). The chemistries of microstructural constituents were determined by energy disperse X-ray spectrum (EDS). The size of the microstructural constituents for EDS analysis was selected such that interference from the surrounding matrix was reduced to the smallest degree possible. SEM/EDS examination was also performed on samples after the creep testing to see if there were further changes in microstructures under stress.

\section{Results}

\section{Mechanical Properties}

The tensile properties of both alloys are listed in Table II. Consistent with previous studies, increased $\mathrm{P}$ and $\mathrm{B}$ in alloy 718 -ER did not noticeably affect tensile properties at either room or elevated temperature. The tensile strength was reduced by thermal exposure at $704^{\circ} \mathrm{C}$ for 1000 hrs. by about $10 \%$ for ultimate and $17 \%$ for yield strength. The reductions in strength were quite similar for both alloys at both temperatures, suggesting minor elements $\mathrm{P}$ and $\mathrm{B}$ have no noticeable effect on microstructural changes controlling tensile strength degradation.

Table II. Comparison of Tensile Properties Between Alloys 718 and 718-ER ${ }^{\mathrm{k}}$

\begin{tabular}{|c|c|c|c|c|c|c|}
\hline \multirow[b]{2}{*}{$\begin{array}{c}\text { Heat } \\
\text { Treatment }\end{array}$} & \multirow[b]{2}{*}{$\begin{array}{c}\text { Test } \\
\text { Temperature } \\
\end{array}$} & \multirow[b]{2}{*}{ Alloy } & \multicolumn{4}{|c|}{ Tensile properties } \\
\hline & & & $\begin{array}{c}\mathrm{YS} \\
(\mathrm{MPa}) \\
\end{array}$ & $\begin{array}{c}\text { UTS } \\
\text { (MPa) } \\
\end{array}$ & $\begin{array}{c}\text { EL } \\
(\%) \\
\end{array}$ & $\begin{array}{l}\mathrm{RA} \\
(\%) \\
\end{array}$ \\
\hline \multirow{4}{*}{ Standard** } & \multirow{2}{*}{$20^{\circ} \mathrm{C}$} & 718 & 1108 & 1427 & 18.8 & 28.0 \\
\hline & & 718-ER & 1096 & 1428 & 16.7 & 19.5 \\
\hline & \multirow{2}{*}{$650^{\circ} \mathrm{C}$} & 718 & 939 & 1133 & 20.8 & 28.3 \\
\hline & & 718-ER & 941 & 1140 & 21.6 & 34.5 \\
\hline \multirow{4}{*}{$\begin{array}{c}+704^{\circ} \mathrm{Cx} \\
1000 \mathrm{hrs}\end{array}$} & \multirow{2}{*}{$20^{\circ} \mathrm{C}$} & 718 & 950 & 1320 & 17.2 & 23.8 \\
\hline & & 718-ER & 927 & 1315 & 15.8 & 20.1 \\
\hline & \multirow{2}{*}{$650^{\circ} \mathrm{C}$} & 718 & 772 & 982 & 29.4 & 51.9 \\
\hline & & 718-ER & 789 & 992 & 27.3 & 46.6 \\
\hline
\end{tabular}

**Note: Standard 718 heat treatment applied to all samples:

$954^{\circ} \mathrm{C} \times 1$ hr.. AC, $718^{\circ} \mathrm{C} \times 8$ hrs.. FC at $55^{\circ} \mathrm{C} / \mathrm{hr}$. to $621^{\circ} \mathrm{C} \times 8$ hrs.. AC

From the stress rupture properties listed in Table III, it can be seen that alloy 718 -ER has much longer rupture life than standard 718 , illustrating again the beneficial effect of $P$ and $B$ in this alloy. However, the magnitude of improvement decreased with increasing test temperature and after long-term thermal exposure. The percentage improvement in rupture life was greater than $112 \%$ at $650^{\circ} \mathrm{C}$, but dropped to about $40 \%$ at $704^{\circ} \mathrm{C}$. and to $30 \%$ and $10 \%$. respectively, after $704^{\circ} \mathrm{C} \times 1000$ hrs. exposure. Compared with tensile properties. a significant reduction in rupture life after thermal exposure was observed. The percentage reduction in rupture life was greater than $82 \%$ at $704^{\circ} \mathrm{C}$ and $94 \%$ at $650^{\circ} \mathrm{C}$ for both alloys. These data imply that the beneficial effect of $\mathrm{P}$ and $\mathrm{B}$ on rupture life is associated with some feature which was changed at the highest test temperature and by long time thermal exposure. 
Table III. Comparison of Stress Rupture Properties Between Alloys 718 and $718-$ ER $^{\mathrm{R}}$

\begin{tabular}{|c|c|c|c|c|c|c|c|}
\hline \multirow{3}{*}{$\begin{array}{c}\text { Heat } \\
\text { Treatment }\end{array}$} & \multirow[b]{3}{*}{ Alloy } & \multicolumn{6}{|c|}{ Stress Rupture Properties } \\
\hline & & \multicolumn{2}{|c|}{$650^{\circ} \mathrm{C} / 759 \mathrm{MPa}$} & \multicolumn{2}{|c|}{$650^{\circ} \mathrm{C} / 690 \mathrm{MPa}$} & \multicolumn{2}{|c|}{$704^{\circ} \mathrm{C} / 620 \mathrm{MPa}$} \\
\hline & & Life (hrs) & EL $(\%)$ & Life (hrs) & EL $(\%)$ & Life (hrs) & EL $(\%)$ \\
\hline \multirow{2}{*}{ Standard** } & 718 & 54.8 & 22.5 & 158.7 & 22.5 & 10.9 & 29.6 \\
\hline & 718-ER & 116.2 & 19.0 & 369.8 & 24.1 & 15.3 & 32.9 \\
\hline \multirow{2}{*}{$\begin{array}{c}+704^{\circ} \mathrm{Cx} \\
1000 \mathrm{hrs}\end{array}$} & 718 & - & - & 9.7 & 33.0 & 2.0 & 35.6 \\
\hline & 718-ER & - & - & 12.9 & 30.0 & 2.2 & 42.1 \\
\hline
\end{tabular}

**Note: Standard 718 heat treatment applied to all samples: $954^{\circ} \mathrm{C} \times 1 \mathrm{hr} ., \mathrm{AC}, 718^{\circ} \mathrm{C} \times 8 \mathrm{hrs} . \mathrm{FC}$ at $55^{\circ} \mathrm{C} / \mathrm{hr}$. to $621^{\circ} \mathrm{C} \times 8$ hrs.. $\mathrm{AC}$

The comparison of creep resistance between alloys 718 and 718-ER can be seen from the data in Table IV and creep curves in Figures 1 and 2. The magnitude of improvement in creep resistance due to $\mathrm{P}$ and $\mathrm{B}$ additions was about $120 \%$ in both minimum creep rate and time to $0.2 \%$ creep strain. similar to stress rupture life increase at $650^{\circ} \mathrm{C}$. The benefit dropped to only $10-15 \%$ after thermal exposure, similar to the results for stress rupture life. The most dramatic change for both alloys was observed in comparing creep properties before and after thermal exposure. There was more than two orders of magnitude reduction in creep resistance after $704^{\circ} \mathrm{C} \times 1000$ hrs. thermal exposure. Alloy 718-ER showed a larger reduction although it still had slightly higher creep resistance.

\section{Microstructure}

Microstructures of both alloys in the as-heat treated condition are shown in Figure 3. No noticeable difference between the two alloys can be seen in terms of grain size and $\delta$ phase particles, even at a magnification of $20,000 \mathrm{X}$ under the SEM. This indicates that the changes in microstructure caused by $\mathrm{P}$ and $\mathrm{B}$ additions are on a much finer scale. Long-term thermal exposure led to dramatic changes in microstructure for both alloys as shown in Figure 4. Three major changes were noted: coarsening of precipitates, formation of a precipitation-depleted zone and formation of large blocky particles. The detailed view of these changes is shown in Figure 5. EDS chemistries of the various microstructural constituents are listed in Table V. The size of both $\gamma^{\prime}$ and $\gamma^{\prime \prime}$ precipitates was significantly increased by the long thermal exposure and the morphology changed as shown in Figure 6 . The $\gamma^{\prime \prime}$ particles maintained a disc-shape with three orientations, and an average length of about $200 \mathrm{~nm}$, slightly greater than that reported in other references $[10,11]$ for similar exposure conditions. No statistically meaningful difference in the size of $\gamma^{\prime \prime}$ particles was found between alloys 718 and $718-E R$, which suggests that the effect of $P$ and $B$ on the growth of $\gamma$ " particles is negligible or the concentration of $\mathrm{P}$ and $\mathrm{B}$ is very low in the grain interior. Gamma prime particles measured about $30 \mathrm{~nm}$, comparable to those reported by others [12], but uncertainty in measurement makes any judgement on the effect of $P$ and $B$ additions on $\gamma^{\prime}$ particle size impossible.

The most striking feature of the thermally exposed samples was the formation of $y^{\prime \prime}$-depleted zone. These zones still had many $\gamma^{\prime}$ particles with a density slightly higher than in the matrix. As expected, the $\mathrm{Nb}$ content of $\gamma "$-depleted zones was much lower than that of the matrix (Table $\mathrm{V}$ ). The slightly higher $\mathrm{Nb}$ and lower $\mathrm{Ti}$ and $\mathrm{Al}$ noted in $\gamma^{\prime \prime}$-free zones of alloy 718-ER are questionable in view of the large scatter in EDS analytical results. It is more likely that $P$ and $B$ additions did not noticeably affect the chemistry of precipitate-depleted zones. No consistent change in size or appearance of precipitate-depleted zones for different $\mathrm{P}$ and $\mathrm{B}$ contents was observed. 
Table IV. Comparison of Creep Properties between Alloys 718 and 718-ER ${ }^{\mathrm{R}}$ (Tested at $621^{\circ} \mathrm{C} / 620 \mathrm{MPa}$ )

\begin{tabular}{|c|c|c|c|c|c|c|c|c|}
\hline \multirow{2}{*}{$\begin{array}{c}\text { Heat } \\
\text { Treatment }\end{array}$} & \multirow[b]{2}{*}{ Alloy } & \multicolumn{5}{|c|}{ Time to $\%$ creep of, (hrs) } & \multirow{2}{*}{$\begin{array}{l}\text { Life } \\
\text { (hrs) }\end{array}$} & \multirow{2}{*}{$\begin{array}{l}\text { Minimum } \\
\text { Creep Rate } \\
\left(\times 10^{-10} \mathrm{~s}^{-1}\right)\end{array}$} \\
\hline & & 0.1 & 0.2 & 0.5 & 1.0 & 2.0 & & \\
\hline \multirow{2}{*}{ Standard** } & 718 & 412 & 865 & - & - & - & $\begin{array}{l}\text { Discontinued } \\
\text { at } 0.2 \% \text { strain }\end{array}$ & 5.51 \\
\hline & 718-ER & 730 & 1890 & - & - & - & $\begin{array}{l}\text { Discontinued } \\
\text { at } 0.2 \% \text { strain }\end{array}$ & 2.50 \\
\hline \multirow{2}{*}{$\begin{array}{c}+704^{\circ} \mathrm{Cx} \\
1000 \mathrm{hrs}\end{array}$} & 718 & 0.16 & 0.55 & 2.1 & 5.5 & 15.6 & 107.2 & 2415 \\
\hline & 718-ER & 0.15 & 0.61 & 2.4 & 6.9 & 20 & 129.9 & 2060 \\
\hline
\end{tabular}

**Note: Standard 718 heat treatment applied to all samples:

$954^{\circ} \mathrm{C} \times 1 \mathrm{hr}$., $\mathrm{AC}, 718^{\circ} \mathrm{C} \times 8 \mathrm{hrs} . . \mathrm{FC}$ at $55^{\circ} \mathrm{C} / \mathrm{hr}$. to $621^{\circ} \mathrm{C} \times 8 \mathrm{hrs}$., $\mathrm{AC}$
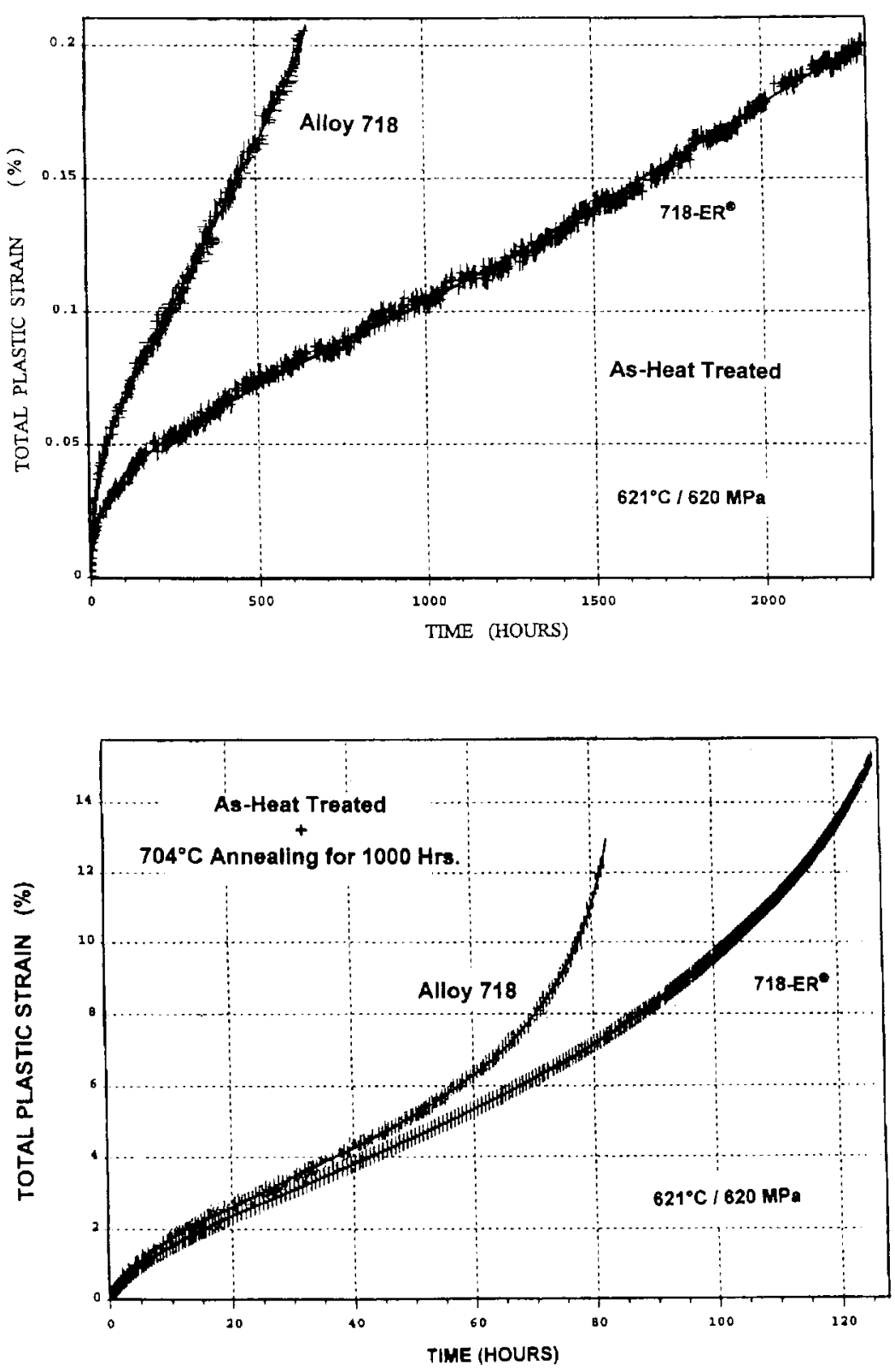

Figure 1. Creep curves at $621^{\circ} \mathrm{C} / 620 \mathrm{MPa}$ of as-heat treated alloys 718 and $718-$ ER $^{\mathrm{R}}$.
Figure 2. Creep curves at $621^{\circ} \mathrm{C} / 620 \mathrm{MPa}$ of as-heat treated $+704^{\circ} \mathrm{C} \times 1000$ hrs. age alloys 718 and $718-\mathrm{ER}^{\mathrm{k}}$. 


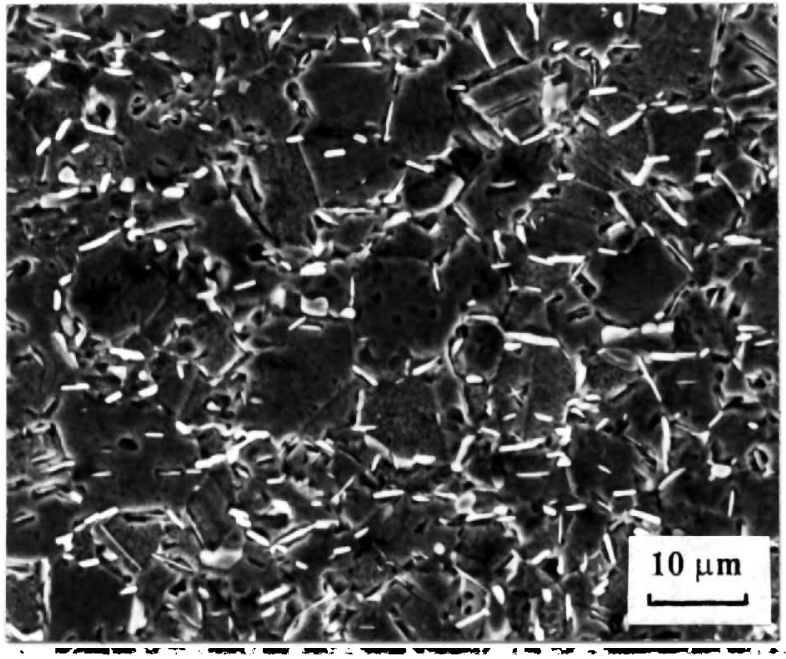

(a)

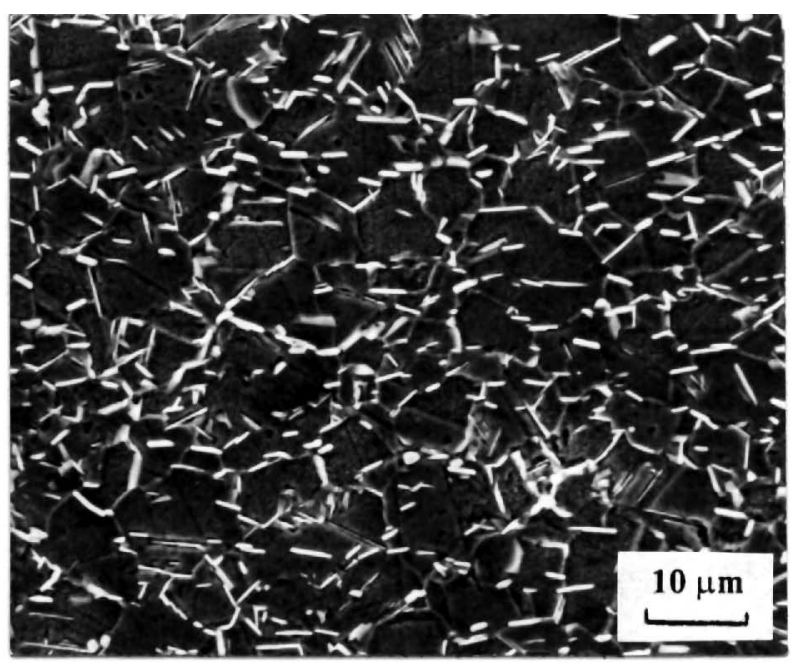

(b)

Figure 3. Microstructure of (a) as-heat treated alloy 718 and (b) alloy $718-\mathrm{ER}^{\mathrm{k}}$

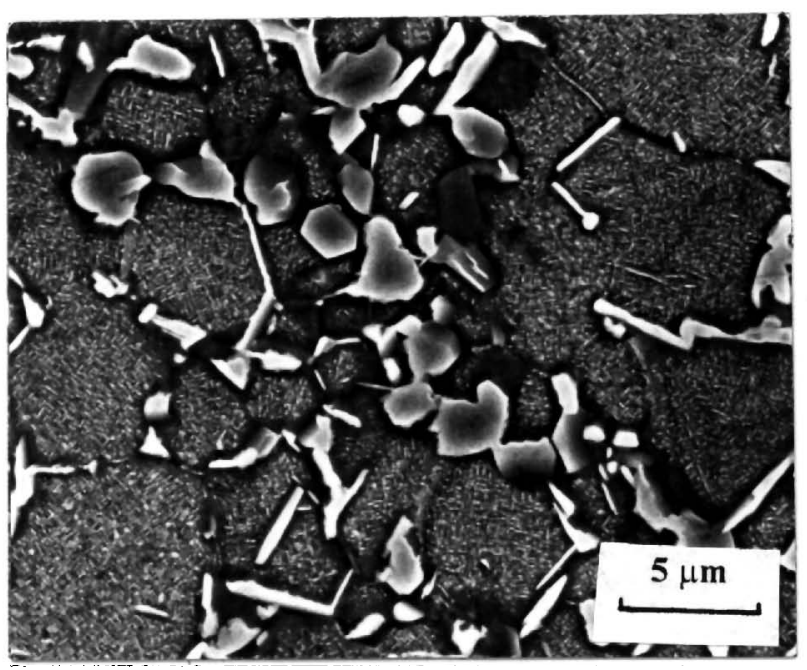

(a)

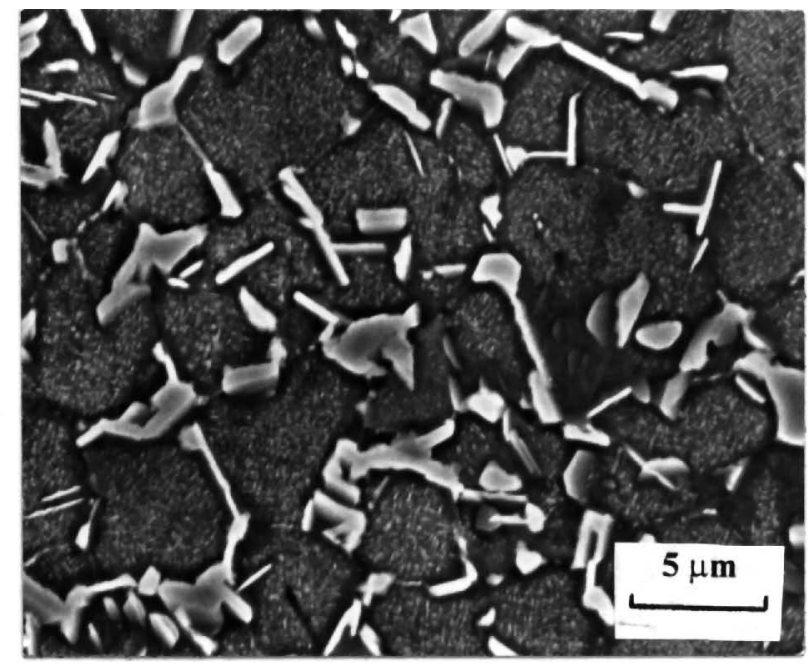

(b)

Figure 4. Microstructure after (a) $704^{\circ} \mathrm{C} \times 1000$ hrs. aging of as-heat treated alloy 718 and (b) alloy $718-\mathrm{ER}^{\overline{\mathrm{K}}}$.

Many large blocky particles were found, mainly at grain boundaries, after thermal exposure ("A" in Figure 5 and Table $\mathrm{V}$ ). They were easily distinguished from $\delta$ phase, which existed before exposure ("D" in Figure 5 and Table V). by their shape and chemistry. The $\delta$ particles were plate or rod shaped and contained higher $\mathrm{Nb}$ content. Their shape did not change, but $\mathrm{Nb}$ content increased slightly following thermal exposure. The blocky particles were slightly higher in $\mathrm{Cr}$ and $\mathrm{Fe}$, but much lower in $\mathrm{Nb}$. After thermal exposure and creep testing, most of the blocky particles had changed to a plate like shape (Figure 7) and their $\mathrm{Nb}$ content increased from about $8-9$ at $\%$ to about 10 at $\%$.

\section{Discussion}

It is well known that alloy 718 is not thermally stable at high temperatures and significant degradation in microstructure and mechanical properties result from long-term thermal exposure, especially at $650^{\circ} \mathrm{C}$ and above. This study showed that different types of mechanical properties 


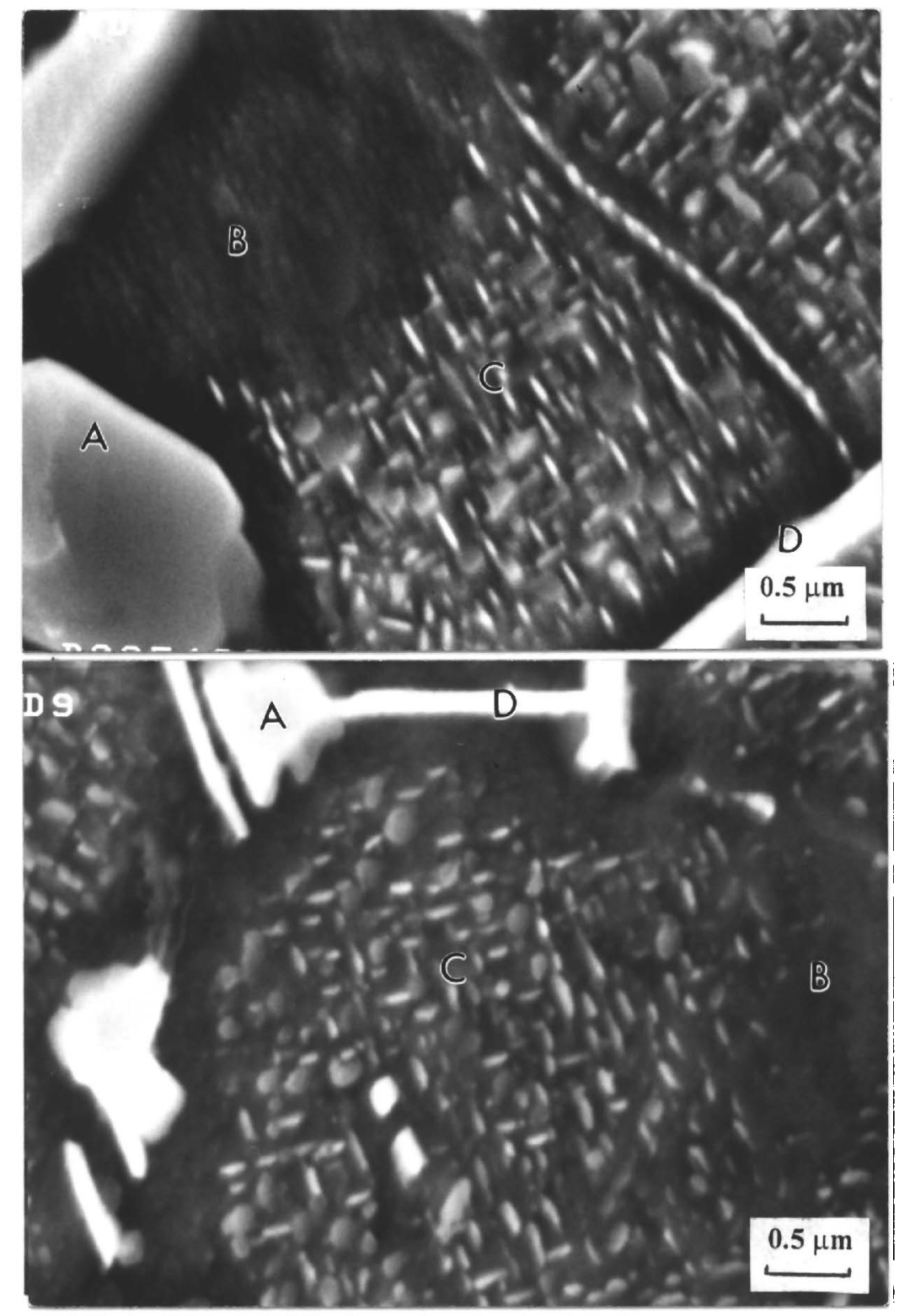

(a)

Figure 5. Detailed view of microstructural constituents (a) after $704^{\circ} \mathrm{C} \times 1000 \mathrm{hrs}$. aging of as-heat treated alloy 718 and (b) alloy $718-\mathrm{ER}^{\mathrm{k}}$ : $\mathrm{A}=$ newly formed blocky particles $\mathrm{B}=\gamma^{\prime \prime}$ precipitate-depleted zone

$\mathrm{C}=$ matrix

$\mathrm{D}=$ rod-shaped particles.

I able 1 . EDs ( hemistry of Microstructural constituents in Figure 5

\begin{tabular}{|c|c|c|c|c|c|c|c|c|c|}
\hline \multirow{2}{*}{$\begin{array}{l}\text { Microstructural } \\
\text { Constituent }\end{array}$} & \multirow{2}{*}{$\begin{array}{l}\text { lleat } \\
\text { Ireatment }\end{array}$} & \multirow[b]{2}{*}{11102} & \multirow[b]{2}{*}{ Ti } & \multicolumn{4}{|c|}{ EDS c hemistry. alt." } & \multirow[b]{2}{*}{110} & \multirow[b]{2}{*}{ N } \\
\hline & & & & $\mathrm{Cr}$ & $\mathrm{Fc}$ & $\mathrm{Ni}$ & $\mathrm{Vb}$ & & \\
\hline I & & 718 & 2.116 & 13.43 & 11.49 & 61.69 & 9.35 & 1.43 & 11.55 \\
\hline Blocky partickes & Standa & $7 / 8-\mathrm{FR}$ & 1.511 & 25.85 & 13.81 & 44.43 & 8.40 & 5.32 & 01.21 \\
\hline \multirow{2}{*}{$\begin{array}{l}\text { B } \\
\text { Precipitate- } \\
\text { depleted aones }\end{array}$} & \multirow{2}{*}{$1000 \mathrm{hrs}$} & 718 & 1.52 & 22.82 & 19.72 & 51.97 & 1.77 & 1.29 & 0.91 \\
\hline & & 71 & 1.14 & 21.81 & 20.02 & 5 & 1.93 & 1.28 & 11.601 \\
\hline \multirow{4}{*}{$c$} & \multirow{2}{*}{ Standard } & 718 & 1.25 & 20.91 & 19.26 & 52.55 & 3.25 & 1.69 & 01.9 \\
\hline & & $718-\mathrm{ER}$ & 1.24 & 20.59 & 18.61 & 53.38 & 3.27 & 1.92 & 11.81 \\
\hline & S1:an & 718 & 1.13 & 211.911 & 19.35 & 52.51 & 2.84 & 1.75 & 1.29 \\
\hline & 101 & $718-\mathrm{LK}$ & 1.04 & 21.114 & 19.56 & 5 & 2.70 & 1.82 & 1.113 \\
\hline \multirow{4}{*}{$\begin{array}{c}\text { D) } \\
\text { Rod-shaped } \\
\text { particles }\end{array}$} & \multirow{2}{*}{ Standard } & 718 & 2.118 & 12.115 & 111.90 & 60.23 & 12.04 & 1.14 & 0.72 \\
\hline & & $718-\mathrm{ER}$ & 2.118 & 13.67 & 11.71 & 59.60 & 11.27 & 1.16 & 0.97 \\
\hline & Standard ${ }^{* \infty}$ & 718 & 1.86 & $\mid 10.81$ & 9.38 & 01.60 & 13.83 & 1.6 .3 & 11.48 \\
\hline & & $718-F R$ & 2.20 & 9,81 & 8.9 .3 & $0,3.01$ & 13.84 & 1.47 & 10.55 \\
\hline
\end{tabular}




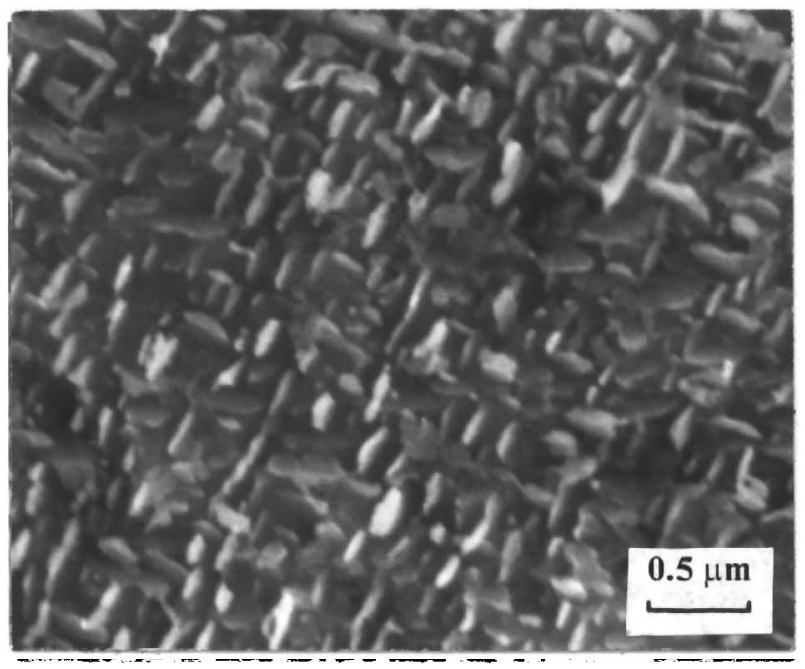

(a)

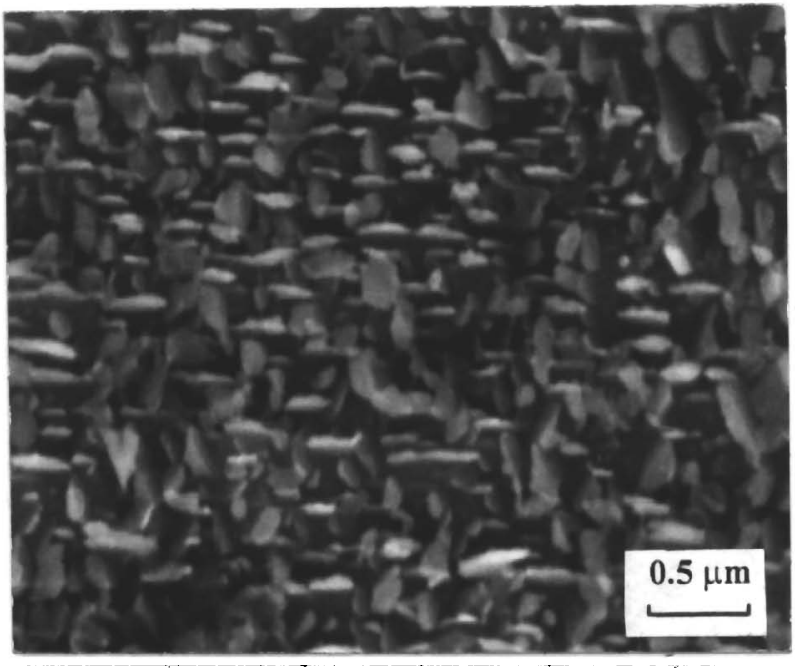

(b)

Figure 6. Morphology of $\gamma^{\prime \prime}$ particles (a) after $621^{\circ} \mathrm{C} / 620 \mathrm{MPa}$ creep test in as-heat treated + $704^{\circ} \mathrm{C} \times 1000$ hrs. age (a) alloy 718 and (b) alloy $718-\mathrm{ER}^{\mathrm{k}}$.

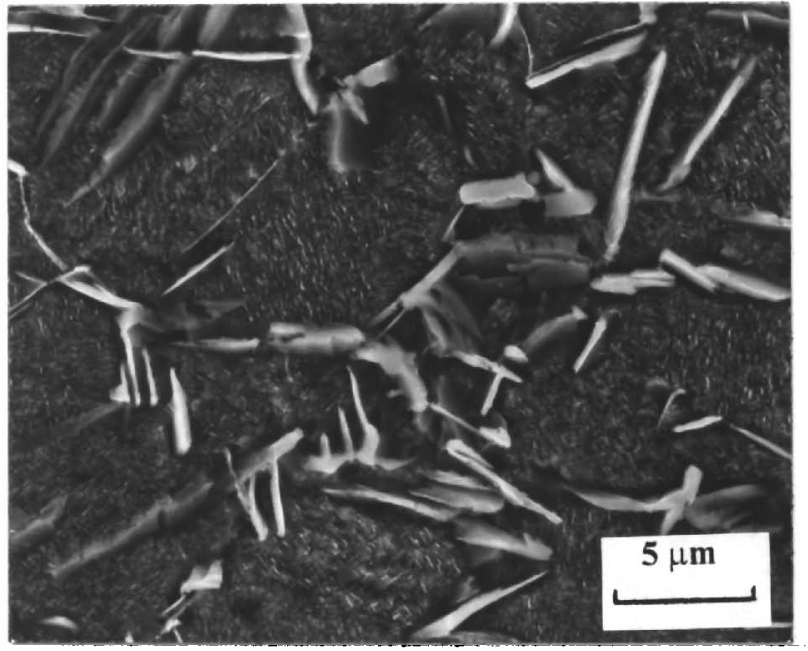

(a)

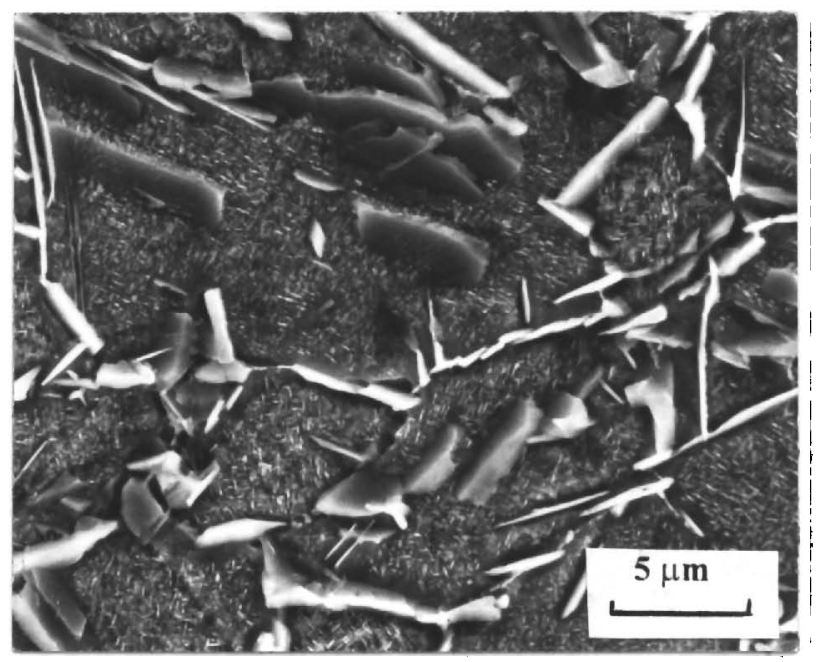

(b)

Figure 7. Microstructure (a) after $621^{\circ} \mathrm{C} / 620 \mathrm{MPa}$ creep test in as-heat treated $+704^{\circ} \mathrm{C} \times$ 1000 hrs. age (a) alloy 718 and (b) alloy $718-$ ER $^{k}$.

had different sensitivity to thermal exposure and the sensitivity was proportional to the length of the test or strain rate involved. Short-term tensile tests had the lowest sensitivity with only a 10 $17 \%$ loss in strength after $704^{\circ} \mathrm{C} \times 1000 \mathrm{hrs}$. exposure. More than two orders of magnitude change was seen in minimum creep rate or creep life time obtained from long-term creep tests. The difference in sensitivity is definitely related to the role of various microstructural changes on specific properties.

The strength of alloy 718 is the function of deformation mode and intragranular precipitate state such as size, inter particle spacing and coherency strain with the latter being the dominant factor [13]. The minor reduction in tensile strength after long time thermal exposure may indicate that the coherency hardening does not significantly decrease, although the $\gamma$ " particle size increased by almost an order of magnitude. 
The reduction in stress rupture life and creep resistance from thermal exposure was most likely controlled by the formation of $\gamma^{\prime \prime}$ particle-free zones. As a general rule, the deformation resistance of superalloys is controlled to a larger degree by near-grain boundary processes as the temperature increases and strain rate decreases. It has been illustrated [14] that the deformation process of grain boundaries determined the creep rate of alloy 718 when $\delta$ phase precipitated along grain boundaries. It is understandable that a significant reduction in stress rupture and creep properties was seen when weak, $\gamma^{\prime \prime}$ particle-free zones were formed. The formation of $y$ " particle-free zones was attributed to $\gamma^{\prime \prime}$ to $\delta$ phase transformation at grain boundaries. Two mechanisms were suggested for this transformation [15]: intragranular nucleation and growth of $\delta$ phase lath on (112) planes of $\gamma^{\prime \prime}$ particles, and $\delta$ phase formation by cellular reaction and growth by exhausting nearby $\gamma^{\prime \prime}$ particles. The latter was presumably responsible for the formation of $\gamma$ " particle-free zones. This study was unable to provide evidence to support or deny the cellular mechanism of $\delta$ phase formation, but did raise some doubt as to whether or not the newly formed particles were true $\delta$ phase. The morphology and chemistry of newly formed blocky particles were significantly different from $\delta$ phase, and most likely these particles were an intermediate product of $\gamma^{\prime \prime}$ to $\delta$ phase transformation. The fact that the morphology and chemistry of such particles gradually approached those of $\delta$ phase under creep stress provided further support to this postulation. All these facts indicate that $\gamma^{\prime \prime}$ to $\delta$ phase transformation at near grain boundary regions proceeded through multiple steps involving dissolution of $\gamma$ " particles, formation of an intermediate product and final transformation to $\delta$ phase. More detailed investigations, such as crystallography and chemical analysis by more sophisticated techniques such as scanning transmission electron microscopy, are needed to clarify this issue.

There have been a number of suggestions regarding the mechanism of the beneficial effect of $\mathrm{P}$ and $\mathrm{B}$ additions in alloy 718 , but experimental and theoretical work has confirmed only one: $\mathrm{P}$ and $B$ increase grain boundary strength. This study revealed another possibility; the beneficial effect of $P$ and $B$ additions might also be associated with the $\gamma$ " particles in alloy 718 . The beneficial effect was very significantly reduced when alloy 718 -ER was subjected to long-term thermal exposure and this reduction paralleled the formation of $\gamma^{\prime \prime}$ particle-free zones. The drop in the strengthening effect of $\mathrm{P}$ and $\mathrm{B}$ additions at higher test temperatures was also concurrent with a weakening of the strengthening effect of $\gamma^{\prime \prime}$ particle at higher temperatures. These facts indicate that there is a relationship between the strengthening effect of $\mathrm{P}$ and $\mathrm{B}$ additions and $\gamma^{*}$ particles, but the details of the interaction are not clear. There was insufficient data to determine if $\mathrm{P}$ and $\mathrm{B}$ have any effect on the kinetics of microstructure degradation, but it appeared that $\mathrm{P}$ and $\mathrm{B}$ modification did not increase the stability of alloy 718 at $704^{\circ} \mathrm{C} \times 1000$ hrs. thermal exposure.

\section{Conclusions}

1. $\mathrm{P}$ and $\mathrm{B}$ additions significantly improved the stress rupture and creep resistance of alloy 718 , but had no noticeable effect on thermal stability at $704^{\circ} \mathrm{C} \times 1000$ hrs. exposure. The dramatic loss of the strengthening effect due to $\mathrm{P}$ and $\mathrm{B}$ additions at high test temperatures and from long time thermal exposure coincided with the loss of $\gamma$ " particle strengthening effect, suggesting that the beneficial effect of $\mathrm{P}$ and $\mathrm{B}$ additions may partially result from the interaction between $\mathrm{P}$ and $\mathrm{B}$ atoms and $\gamma^{\prime \prime}$ particles. The detailed mechanism needs further investigation.

2. Significant microstructural changes occurred in alloys 718 and 718 -ER during thermal exposure at $704^{\circ} \mathrm{C}$ for 1000 hrs. including coarsening of $\gamma^{\prime}$ and $\gamma^{\prime \prime}$ particles. and formation of $\gamma^{\prime \prime}$ precipitate-free zones and large blocky particles containing higher Nb. The newly 
formed blocky particles were most likely an intermediate product of $\gamma^{\prime \prime}$ to $\delta$ phase transformation. No noticeable difference in microstructural changes was found in alloys 718 and $718-E R$.

3. Different mechanical properties had different sensitivity to thermal exposure. Tensile strength had the lowest sensitivity with a 10-17\% drop. The reduction in tensile strength was probably controlled by intragranular precipitates. Creep resistance had the highest sensitivity with greater than two orders of magnitude reduction. The formation of $\gamma^{\prime \prime}$ precicipate-free grain boundary zones likely play a more important role in this property change.

\section{References}

1. W.D. Cao and R.L. Kennedy, Superalloys $718,625,706$ and Various Derivatives, ed. E.A. Loria, (TMS, 1994), 463-477.

2. W.D. Cao and R.L. Kennedy, Superalloys 1996, ed. R.D. Kissinger et al., (TMS, 1996), 589-597.

3. R.L. Kennedy, W.D. Cao and W.M. Thomas, Advanced Materials \& Processes, Vol. 150, (1996), No. 3, 33-34.

4. W.D. Cao and R.L. Kennedy, Superalloys 718, 625, 706 and Various Derivatives, ed. E.A. Loria, (TMS, 1997), 511-520.

5. W.D. Cao and R.L. Kennedy, Superalloys 2000, ed. R.D. Kissinger et al., (TMS, 1996), 589-597.

6. D.F. Paulonis, J.M. Oblak and D.A. Duvall, Trans. ASM, Vol. 62, (1969), 61 1-622.

7. R. Cozar and A. Pineau, Metall. Trans., Vol. 4, (1973), 47-59.

8. J.W. Brooks and P.J. Bridges, Superalloys 1988, ed. S. Reichman et al., (TMS, 1988), 33-42.

9. M.K. Miller, J.A. Holton, W.D. Cao and R.L. Kennedy, J. Phys. (France). Colloq. C5, (1996). Vol. 6, $241-246$.

10. E. Andrieu, R. Cozar and A. Pineau, Superalloy 718 - Metallurgy and Applications, ed. E.A. Loria, (TMS, 1989), 241-256.

11. Dong Jianxin, Xie Xishan and Zhang Shouhua, Scripta Metall. et Mater., Vol. 33, 1995, 1933-1940.

12. J.K. Tien, J.P. Collier and G. Vignoul, Super Alloy 718 - Metallurgy and Applications, ed. E.A. Loria. (TMS. 1988), $553-566$.

13. J.M. Oblak, D.F. Paulonis and D.S. Duvall, Metall. Trans., Vol. 5, 1974, 143-153.

14. W. Chen and M.C. Chaturvedi, Can. Met. Quat. Vol. 32, 1993, 363-367.

15. M. Sundararaman, P. Mukhopadhyay and S. Banerjee, Metall. Trans. A. Vol. 19A, 1988, $453-465$. 